\title{
The Hungarian Revolution of 1956 and Its Consequences for the Ikarus Bus Factory
}

\author{
Technology, Workforce and Power Relations
}

\author{
Zsombor Bódy
}

In scholarly work dealing with the Hungarian Revolution of 1956, emphasis with regard to factories has been placed largely on the political activities and influence of the workers' councils, which were revolutionary in spirit. ${ }^{1}$ Attention has also been paid to the suppression and disbanding of these councils after the defeat of the uprising. This is understandable, since for a short time the workers' councils did indeed represent a threat or challenge to the Kádár regime, which was trying to consolidate its hold on power after having been installed by the Soviet troops.

As Hannah Arendt has observed, in the case of the Hungarian revolution which in her view was the only real workers' revolution in the twentieth century - it is worthwhile to make a distinction between the workers' councils and the other councils, which were hastily formed and had political goals. "At any event, the Revolutionary and the Workers' Councils, though they emerged together, are better kept apart, because the former were primarily the answer to political tyranny, whereas the latter in the case of the Hungarian revolution were the reaction against trade unions that did not represent the workers but the party's control over them". ${ }^{2}$ However, the emphasis in later scholarship was on the political and armed clashes. Accordingly, questions about the conditions in the factories at the outbreak of the revolution and the state of the factories themselves were relegated to the background; as was

1 István Kemény and Bill Lomax, Magyar munkástanácsok 1956-ban (Dokumentumok) [Hungarian Workers' Councils in 1956 (Documents)] (Paris: Magyar Füzetek, 1986); Imre Varjasi, Az 1956-os munkástanácsok tevékenysége és dokumentumai Hajdú-Bihar megyében [The Works and Documents of the 1956 Workers' Councils in Hajdú-Bihar County] (Hajduböszörmény: Fábián, 2008); József Géczi and Éva Szrenka, 8 napért 8 év. A munkástanácsok 1956-ban és ami utána jött ... [Eight Years for Eight Days. The Workers' Councils in 1956 and what Came in their Wake] (Szeged: Bába, 2012). This research was carried out within the frame of 'MTA - SZTE - ELTE History of Globalisation Research Group'.

2 Hannah Arendt, The Origins of totalitarianism (Cleveland and New York: World Pub. Co., 1964), 498. Not all of the editions include the chapter on the Hungarian revolution.

(C) ZSOMBOR BÓDY 2021 | DOI:10.1163/9789004440395_007

This is an open access chapter distributed under the terms of the CC-BY-NC 4.o licenşe.ombor Bódy - 9789004440395 
the question of the extent to which the revolution and its fall brought about changes in the relationships among the various groups in the inner world of the factories (and if so, then how). ${ }^{3}$ Nevertheless, the actions and roles of the workers' councils during the revolution were not limited entirely to the national political context. If one considers the events of the revolution that took place at the factory level, then it quickly becomes apparent that - like other dramatic upheavals that stirred the masses - to a significant extent the Hungarian Revolution of 1956 constituted an outburst of tensions that were not tied directly to the spectacular events of national politics at the time, and even less to political ideologies or conscious political stances. These tensions had built up more in everyday life, particularly in the workplace and in relations between workers and plant directors. Thus, to further a more nuanced understanding of the causes and the consequences of the revolution, these tensions should not be analysed exclusively from the perspective of political theory or great power politics, but also from the perspectives of everyday life and the workplace.

The "corrective measures" taken by the Soviets after Stalin's death in 1953 to reform the Rákosi regime's dictatorial approach to rule fragmented the regime in Hungary and created factions within the power structure that turned against one another. This was of crucial importance in the path that led to the outbreak of the revolution three years later. Because of these divisions, the regime was unable to deal with the very real social tensions. Thus, the attempt by the Soviets to address the situation - which in their assessment was already on the verge of exploding in 1953 - failed. The approach that relied on the use of force (in this case, violence), which from time to time had gained the upper hand, also failed to stifle people's calls for change. Instead, the proverbial genie had been let out of the lamp. By October 1956, students in Hungary and the youth movements had become unmanageable by the authorities, because they had been joined by broad strata of the working class. It only took the Soviet troops, who returned to Hungary to quell the revolution on 4 November, about a week to defeat the Hungarian forces. However, for quite some time, the workers' councils in the factories remained a significant opposition force to the Kádár government, which had arrived in Budapest quite literally on the back of Soviet tanks. The central workers' councils, which consisted of delegates from the workers' councils of the individual factories, were forcefully dissolved before Christmas 1956. However, in the

3 For example, Zoltán Ripp, Forradalom és szabadságharc Magyarországon 1956-ban [Revolution and Freedom Fight in Hungary 1956] (Budapest: L'Harmattan, 2002). 
factories, the workers' councils that had been freely chosen during the few days of revolutionary freedom, continued to function, and it took the regime months to subdue them. ${ }^{4}$

Thus, the conduct and activities of workers and labourers in factories were of crucial importance in the unfolding of the revolution and the continued resistance against the Soviet forces, even after the military forces fighting against the Soviets had been defeated. Their decisions and actions, however, were shaped by tensions that had become increasingly palpable in the years before the revolution. These tensions were aggravated by technological circumstances, the prevailing work culture and the expectations of the regime. Historians, however, have only rarely devoted any energy to this subject.

Based on the secondary literature on the earlier and later periods, one would have every reason to assume that the inner world of the factories was rife with conflicts and tensions, both before and after the revolution. ${ }^{5}$ The political upheaval certainly did not leave the power relations between the different groups in the factories unchanged (for example the skilled labourers, the technicians and the factory managers). In the current chapter, I examine the events that took place at, and the shifting relations within, the Ikarus Car Body and Motorized Vehicle Factory (which primarily produced buses) during the Hungarian Revolution of 1956. I seek first and foremost to present the mediumterm changes in the operations of the factory that came about as a result of the revolution. In order to put these into context, I begin by examining the conditions and internal relations within the enterprise before the outbreak of the revolution, and subsequently the manner in which the factory was run in the period after it. Thus, I do not limit myself narrowly to the relatively short period of the revolution itself and the repressive measures taken in its wake, but instead I examine the shifts that took place at Ikarus in a broader temporal framework (roughly from 1950 to 1960). In order to offer an accurate assessment of the effects of the revolution, I examine the relationships and power

4 A short summary of the history of the revolution can be found in János M. Rainer, "The Hungarian Revolution of 1956: Causes, Aims and Course of Events", in The 1956 Hungarian revolution: Hungarian and Canadian Perspectives, ed. Christopher Adam, Tibor Egervari, Leslie Laczko and Judy Young (Ottawa: University of Ottawa Press, 2010), 12-31.

5 Gyula Belényi, $A z$ állam szorításában: Az ipari munkásság társadalmi átalakulása Magyarországon, 1945-1965 [In the Grip of the State. The Social Transformation of the Industrial Working Class in Hungary, 1945-1965] (Szeged: Belvedere Meridionale, 2009); István Kemény, Velük nevelkedett a gép. Magyar munkások a hetvenes évek elején [The Machine was Raised with Them. Hungarian Workers at the Beginning of the 197os] (Budapest: Művelődéskutató Intézet, 1990). 
hierarchies between the groups and the individuals who played important roles in the operations of the enterprise in the relevant period. The revolution should accordingly not be understood as a single point that can be detached from the flow of events, but as an intersection of processes that were underway at the time; processes that were given a new direction by the revolution itself, at least in part. What was this new direction, and to what extent did it influence shifts in relations at Ikarus?

In 1956, the Ikarus factory was a plant in operation in Mátyásföld, an area on the outskirts of Budapest. Investments in the first half of the 1950s notwithstanding, the Mátyásföld factory unit continued to function essentially on the same scale as it had done when it was built during the Second World War as the Uhri Brothers' Automobile Bodywork and Motorized Vehicle Factory. When the revolution broke out, the factory was employing approximately 4,0oo workers. Plans had already been made for the plant to acquire a form of monopoly as the sole provider of large buses for the entire Eastern Bloc, though this was only actually realized towards the end of the 1960s. The plant, however, was still one of the most important motor vehicle enterprises in Hungary at the time. When the revolution started, the earlier plant management was removed and control shifted to the workers' council and a few directors, who until then had been on the second level of the management. All the signs suggest that the workers' council and the new management were able to work together effectively. Some of them were later affected in one way or another by the reprisals that were taken following the defeat of the revolution, including István Cséfalvay (head of the design division), head engineer Béla Zerkovitz (the son of operetta and pop music composer Béla Zerkovitz, who was well known in Hungary) and Emil Hant (the chief accountant).

A monograph written at what could be called the height of the Kádár period and describing the history of Ikarus Factory in Hungary, offers the following assessment of their roles:

The fact that, after 4 November, ${ }^{6}$ the [people] mentioned offered assistance to anti-communist measures can be considered political naïveté, lack of experience, and short-sightedness. With these acts, they not only sinned against their own workers, their past, and their earlier friends, they also - locking themselves out of life at the company - rejected the amazing and unbelievable development, development which had risen

6 This was when the soviet invasion of the country began and the Kádár government started to be formed. 
almost from nothing, of which they themselves had been the initiators, directors, active participants, and soldiers. ${ }^{7}$

Neither Cséfalvay, Zerkovitz nor Hant remained at Ikarus after the revolution. In 1957, along with many others, they left the company. Hant was arrested and condemned, as was Ignác Balogh, the chairman of the workers' council. Although not explicitly, the monograph suggests that some of the failures in connection with the development of new types of buses were consequences of the revolution. ${ }^{8}$ In other words, the departure of some of the technical staff leaders and skilled employees brought an end to the "amazing and unbelievable development" of the company. According to the monograph, the acts committed by the people in question, and their general conduct during the revolution, were due to their "political naïveté" and "lack of experience", although the consequences were dire, both for them personally and for the company. In total, according to the monograph, 26 people - mainly workers - were arrested in the wake of the revolution.

I first offer an overview of the "amazing" development of the company in the period before the revolution, and political experience of the people at the company who ended up taking part in the revolution. In fact, these people were not "lacking" in political experience by any measure, the contention found in the aforementioned monograph notwithstanding. I continue my discussion with an examination of what took place at the Ikarus factory in Mátyásföld (now within district XVI of Budapest) during the revolution, and the way in which repressive measures were implemented in 1957. Lastly, I describe the consequences of the fall of the revolution up to the mid-196os.

\section{Operations at the Ikarus Factory before the Revolution}

In order to understand the course of events during the revolution, and their consequences, one needs to know something about the history of the factory in the decade between the end of the Second World War and the outbreak of the revolution. The factory was nationalized in 1947, which was before the wave of nationalization that took place in 1948 . The position of managing director changed hands relatively frequently. Béla Zerkovitz, however, was given

7 Károly Jenei and József Szekeres, Az Ikarus Karosszéria - és Jármügyár története 1895-1980 [The History of the Ikarus Bodywork and Motorized Vehicle Factory, 1895-1980] (Budapest: Ikarus Gyár, 1981), 160-161.

8 Ibid, 173 . 
the job of chief engineer in the summer of 1947, and remained in this position until the tumultuous days of October 1956. István Cséfalvay had been given the position of head of the design division at the beginning of the war. Thus, these two Ikarus employees were at the plant for a relatively long time. This was important, because in the second half of the 1940s, the factory was at the intersection of various conflicts of interest (the effects of which were still being felt in the 1950s), and new internal tensions were added to these clashes.

In 1946, the plant started to become an arena for conflicts of interest between the Social Democratic Party and the Communist Party. Both sought to recruit Ikarus workers into their organizations. The Social Democratic Party was far more successful in its efforts, until the two parties were forcefully united. The two "workers' parties" nevertheless had strikingly different visions for the role of the plant in the economic policies of the country. The Social Democratic Party had planned on procuring the vehicles necessary for mass transportation in Hungary by relying on foreign imports. By contrast, the Communist Party had wanted to produce buses domestically, and had planned to use the Ikarus factory in part to address this need. When the political struggle between the two parties at the national level came to an end and the Communist Party emerged victorious, it prevented the Budapest Capital Transportation Joint Stock Company (the enterprise responsible for transportation in Budapest) from being able to order buses from abroad. In the Ikarus factory, the social-democratic organization was eliminated, and the positions of power within the plant were occupied by communist party activists. However, some people who assumed central positions in the network of the social-democratic organization in the plant before 1948 remained employees of Ikarus. Balogh who served as chairman of the workers' council during the revolution - was one of them, as was Béla Grandits, who was the chairman of the Üzemi Bizottság (Plant Committee) before the nationalization of Ikarus and who became deputy chairman of the workers' council in 1956 .

After 1948, when foreign imports were banned for political reasons, the actual delivery of buses at the necessary scale in Hungary constituted a challenge that the domestic industry and Ikarus were only able to meet with considerable difficulties, and only at a questionable standard from the perspective of quality. One of the difficulties was the lack of suitable-sized modern engines. This was again a source of conflict between people who supported acquiring the necessary materials abroad and purchasing foreign licenses, and those who preferred the idea of developing and producing the engines in Hungary. The first solution was expensive. The cost of the second solution was also an issue, but equally importantly it would only have been possible after development work had been carried out. It was not easy to say how long this would have 
taken, since the process of designing an engine and perfecting it through series of time-consuming tests would itself take a great deal of time. ${ }^{9}$

Ikarus, however, was affected more directly by other design questions concerning bus production, since the company did not manufacture its own engines. As part of their vision for cost-effectiveness, the politicians responsible for decisions concerning economic policy wanted the engines and the chassis for the buses to be made using the same main parts that were used for lorries. The engineers at Ikarus, however, knew that it was not possible to design modern buses that would meet the users' expectations of them (that they should be comfortable, efficient and relatively inexpensive to use and maintain) using lorry chassis. After the Second World War, the production of buses all over the world essentially separated once and for all (in terms of the technology involved) from the production of trucks. Buses with self-supporting bodywork were considered pioneering experiments within the industry. This shift in the industry was in part a consequence of a change to the production of aeroplanes that had taken place during the war, because the self-supporting bus bodywork was based essentially on an adaptation of the construction methods used to make aircraft fuselages. During the war, the Ikarus factory was used for the production of aeroplanes, and the industrial knowhow gained in this process was then applied to the production of buses. Thus, with regard to fundamental technical issues concerning bus production, Zerkovitz and Cséfalvay - the chief engineers - were in constant conflict with the higher authorities that were in charge of the plant. ${ }^{10}$

Béla Zerkovitz, "Újabb irányok az autóbusz építésben [New Directions in the Construction of Buses]", Magyar Technika: Müszaki és gazdaságtudományi folyóirat [Hungarian Technic: Journal of Technological and Economic Science] no. 4 (1949): 45-51. Béla Czére and László Prohászka, Hazai Gépjármúközlekedésünk fejlesztése: A Magyar Tudományos Akadémia Közlekedéstudományi Föbizottsága és a Közlekedési Minisztérium által 1952. július 11-12-én rendezett első Gépjármüközlekedési Ankét előadásai és hozzászólásai [The Development of Domestic Motor Vehicle Transportation: Compiled from the material of the presentations and comments of the first Motor Vehicle Transportation Conference, organized on 11-12 July 1952 by the Main Transportation Sciences Committee of the Hungarian Academy of Science and the Ministry of Transportation] (Budapest: Közlekedési Kiadó, 1953).

10 With regard to the early years of the Ikarus factory, see Zsombor Bódy, "Egy szocialista járműipari vállalat születése [The Birth of a Socialist Enterprise in the Automobile Industry]", Korall 52 (2013): 91-112; Jenei and Szekeres, Az Ikarus Karosszéria - és Jármügyár. According to Jenei and Szekeres, there were continuous struggles surrounding "the oppositional elements among the engineering experts", who were nonetheless irreplaceable at the factory. Regrettably, Jenei and Szekeres offer no details concerning the individuals or the struggles in question. Cséfalvy, who had grown up in Czechoslovakia as a member of the Hungarian-speaking minority, had studied at the technical university in Brno. He came to Hungary following the First Vienna Award, a treaty signed following the 
The organizations in charge of economic policy insisted that Ikarus should design buses on the basis of the lorry bodywork that was made at the Csepel Automobile Factory. The proposals that were devised by Ikarus, which recommended developing buses with self-supporting bodywork, were rejected. Therefore, the designers at the factory worked on plans for the buses they were expected to provide. Nevertheless, Cséfalvay and Zerkovitz did not give up on the idea of using self-supporting bodywork and they continued to work on designs for these vehicles, while of course continuing to develop designs as requested by the policymakers. Thus, in a way, they resisted the expectations of the higher authorities, by working as employees of the company on an idea that, in their view as engineers, was preferable. However, this was without having any authorization to do so. Finally, in the summer of 1951, the authorities gave permission for plans to construct buses with self-supporting bodywork, though alongside rather than instead of work on ones designed for the Csepel bodywork. For quite some time, the work on these two different types of designs did not actually yield practical, functional models. It was not until 1955, with the production of the Ikarus 55 model, that a self-supporting bus was actually made by the plant, and that could be regarded as a success.

In addition to the conflict concerning matters of technology and engineering (which was also, of course, a conflict of personalities and personal interests), there was also an internal affairs aspect. Zerkovitz had been under continuous observation by the secret police since 1952. They believed he had been making mistakes that impeded completion of the plans issued by the regime and hurt the national economy. They also thought that he had been breaking various resolutions issued by the Council of Ministers. The secret police could not prove that Zerkovitz's "mistakes" were deliberate sabotage, but they suspected it. They also suspected him of hindering the labour competition movement, ${ }^{11}$ and the switch from hourly wages to piece rates, which was one of the most important tools used by the regime in striving to improve production

partitioning of Czechoslovakia in 1938 (the Award ceded significant territories in southern Czechoslovakia, which were populated largely by Hungarian speakers, to Hungary). In 1945, Cséfalvy became a member of the Hungarian Communist Party, and later joined the Hungarian Workers' Party, so he could not have been characterized as an "oppositional element". Zerkovitz could, however, as he had originally belonged to the Social Democratic Party.

11 A strategy used by the regime to motivate workers by placing them in competition with one another and offering rewards to those who outdid their peers. It is also known as the Stakhanovite movement, after Aleksei Grigorievich Stakhanov, a coal miner in the Soviet Union who allegedly produced more than fourteen times his quota in 1935 and who was made the paragon of the overachieving socialist worker. 
following the introduction of a command economy. The labour competition movement did not serve simply as a means of providing evidence that workers were indeed labouring enthusiastically to further the construction of the socialist state. It was also intended to improve the pace of work by emphasizing the importance of performance and production..$^{2}$ Other sources mention the accusation against Zerkovitz concerning the shift from hourly wages to piece rate, and it seems likely that there was ongoing tension at Ikarus about wages. According to the official monograph of the Kádár era mentioned at the beginning of this essay, for the Ikarus factory, the collective agreement negotiated - or rather, imposed - following nationalization was a tremendous disappointment for the workers. According to the text of the monograph, this was because in their negotiations with the "capitalists", the trade unions had managed to reach an arrangement over wages that the company simply could not afford. The real reason, however, lay in the conflict and struggle between the two so-called workers' parties. The members of the factory committee (a body brought into being by law in 1945 with the task of exercising oversight over companies in labour affairs), most of whom were Social Democrats, continuously raised the workers' wages in order to ensure that the Hungarian Communist Party organization at the plant would not be able to undermine them and drum up support for their own party by making demands for better pay. ${ }^{13}$ At Christmas time in 1951, around 100 workers were arrested after a riot, which broke out because of the timing of wage payments. ${ }^{14}$ The assessments of the factory that were carried out at the time by the higher authorities overseeing economic policy also noted tensions concerning the form of the wage system and the amounts that were paid.

According to a factory assessment dated 3 October 1952, only slightly more than half of the manual labourers were employed on a piece rate basis. The rest were paid hourly wages, though the goal was to have as many employees as possible on piece rate, which was supposed to motivate them to work more efficiently. The assessment noted several other problems, including the management of materials and the storage of tools. The most important problem,

12 Miklós Haraszti, Darabbér: Egy munkás a munkásállamban [Piece Rate: A Worker in the Workers' State] (Budapest: TE KA Könyvk., n.d.).

13 Bódy, "Egy szocialista járműipari vállalat".

14 Jenei and Szekeres, Az Ikarus Karosszéria - és Jármügyár, 126. The proceedings lasted for years, with the various party organizations at different levels making decisions, and the appeals submitted by those effected in the case of party members who had taken part in the uprising. Budapest Főváros Levéltára, XXXV 157 a 3. A Budapesti MDP Pártbizottság üléseinek iratai. 
however, was that only half of the manufacturing work (or during the most productive periods only two-thirds) carried out was in accordance with an appropriate operations plan..$^{15}$ According to a domestic affairs report on Zerkovitz's performance at the time, he would allow the work (being carried out in order to reach the goals set by the authorities) to fall behind during normal working hours. In this way, he would then need the employees to work overtime, for which they were naturally paid more, thus incurring additional costs for the factory and the state. ${ }^{16}$ It is quite possible that Zerkovitz used this strategy to alleviate tensions at the factory concerning wages, which also at least in part explains why, during the revolution, he was one of the factory leaders who were able to remain in their position. Indeed, he even gained some room for manoeuvre. As someone who had the trust of the workers, he was able to push through personnel changes at the plant's head of department level during the revolution. ${ }^{17}$

A source that was produced after 1956 sheds light from a distinctive perspective on the earlier problems with production in the factory. In 1958, the regular annual factory assessment again noted serious failings at Ikarus, for which the management was blamed. Chief engineer Antal Hirmann, who was Zerkovitz's successor, wrote a long report dated ${ }_{31}$ December $195^{8}$ in which he offered an explanation in a very personal tone. According to Hirmann's report, the "counterrevolutionary events of 1956 had a decisive effect on life at the factory. Precisely for this reason, I must touch on operations at the factory before 1956". Hirmann, who had worked at the factory before 1956, did not dispute the contentions that were made in the annual assessment. He merely felt that these observations could only be understood properly if seen in their historical context. That is, with some grasp of operations at the factory before 1956 and

15 Hungarian National Archives box XXIX F 187 - r 178. Ikarus Bodywork and Motorized Vehicle Factory. The reports drawn up after factory assessments in previous years (which are also held in this box in the archive) clearly reveal that the factory was continuously struggling with major losses. After nationalization, it was given a large injection of capital in order to settle debts from the previous period and to address the lack of floating capital, but capital remained a problem and every year new subsidies were given, even though the volume of production grew quickly. In financial terms, the plant was not viable.

16 Historical Archives of the Hungarian State Security 3.19. V-141867. The investigation dossier on Dr Emil Hant and Associates.

17 According to the report submitted by resident "Rezső Németh", Zerkovitz often put the managing director of the company in a difficult position when he let employees work overtime in order to complete a task or promised to give workers bonuses for which no money had been set aside by the people in charge of budgeting. Thus, the managing director (whichever one happened to be holding the position at a given time), who was always trying to cut wage costs, always looked bad in the eyes of the workers. Ibid. 
an understanding of the consequences of the revolution. The most significant problem, according to the assessment, was that buses were being produced without the necessary documents for the plans and the methods involved. There were no technical drawings illustrating the processes for assembling the various parts, nor was there even a proper inventory of the parts that needed to be assembled. These failings led to problems with the quality of the buses that were produced, and significant inconsistencies, meaning that there were undocumented variations in one model of bus. Models that were manufactured and delivered, and were in principle part of the same series, were in fact not identical.

Hirmann offered an explanation that concerned the circumstances at the factory before 1956. The plant did indeed produce the models in the series, which were manufactured in relatively small numbers, "under the oversight of several of the superb engineers at the plant ... and a relatively large number (considering the number of vehicles manufactured) of first-class skilled workers" without the technical documentation that would have been necessary for standardized production. According to Hirmann, they simply did not have the capacity to produce the technical drawings that would have been necessary as a form of detailed documentation, since they would have had to produce the corresponding technical drawings and descriptions for several different smaller series ( 50 per cent of which were made for military purposes). Hirmann insisted that the management had indeed sought to enforce discipline, compelling employees to adhere strictly to the expectations placed on them, but "this ambition was also defeated by the opposition with which it was met in the workshop". In other words, when it came to the production of buses, the plant relied to a large extent on the experience and knowledge of its engineers, and first and foremost its skilled labourers, who performed the tasks they were assigned without precise documentation. The production of the motor vehicles, or more precisely, the assembly of principal parts that were produced elsewhere, and the manufacture of the bodywork (the only part of the vehicles that Ikarus actually manufactured) rested on an industrial work culture in which the bodywork mechanics were the key figures. At the plant, they were referred to as "emperors of sheet metal", able to produce any type of bodywork panel with a small amount of mechanized labour. ${ }^{18}$ Clearly, they were people

18 Pál Michelberger makes mention of the "emperors of sheet metal". Michelberger started working at Ikarus after 1956, and he later became one of the directors of the so-called Public Roads Motorized Vehicle Development Programme. As part of this programme, at Ikarus - where changes had been made to attain the highest possible production numbers - high-performance pressing machines were developed and 
who did not consider the technical documentation, which specified precise standards, terribly important. As Hirmann remarked in his report,

the workers consider the documentation completely unnecessary, and only after considerable re-educational work has been done will they be persuaded to consider this question important to them, since at the moment they see only the unpleasant side.... This leads to particularly challenging problems in the case of a few of the old trained labourers who really can work..$^{19}$

The production capacity and work culture at Ikarus were consequences of the economic circumstances during the war. The employees who were part of this culture had worked at the plant either during the war (for instance Cséfalvay, whose knowledge of engineering was highly valued by his successors) ${ }^{20}$ or immediately after it.

\section{2 \\ The Revolutionary Events and Their Aftermath}

For the most part, work at the factory came to a halt in the immediate wake of the events of 23 October 1956. In response to the news concerning the political upheavals, many employees did not go to their workplace. On 28 October, a workers' council was formed at the Ikarus factory, in which the managing director and other members of the factory leadership took part. Originally, this was on the initiative of the ruling party itself, as was the case at other factories. The regime hoped that the factory workers' councils would serve as buttresses against armed insurrections. Ultimately, things went very differently, since the factory workers' councils across the country ended up supporting the demands of the revolution. These demands included holding people who had taken part

produced. See Pál Michelberger, "Előszó [Preface]", in Földön - vizen - levegőben. Uhri testvérek története 1941-1942 [On the Ground - In the Water - In the Air. The Story of Uhri Brothers, 1941-1942], ed. Finta László (Budapest: Finta László, n.d.). Michelberger later became the dean of the Faculty of Transportation Engineering at the Budapest University of Technology, and subsequently rector of the university. See the collection of interviews with him, Zsuzsa Szentgyörgyi, Mérnök - tudós - iskolateremtö. Michelberger Pál és kora [Engineer - Scholar - School Creator. Pál Michelberger and his Era] (Budapest: Typotex, 2008).

19 Hirmann's report. Hungarian National Archives, XXIX F 187-r 178.

$20 \quad$ See Michelberger's assessment, Michelberger, "Előszó". 
in the earlier regime responsible, arranging elections and, first and foremost, the withdrawal of Soviet troops from Hungary. ${ }^{21}$

According to Balogh's later confession to the investigators, the first workers' council at the Ikarus plant had not been elected. It had instead been appointed, because on that particular day (28 October) there had been very few workers in the factory. Balogh had been entrusted essentially with the position of chairman by members of the company management. We do not know why someone who had been employed as a mechanic at the Ikarus factory was considered suitable for this role. Two days later, when there were more workers at the plant, they demanded that the members of the council should introduce themselves at an assembly, and when some of the names were announced, the workers expressed their disapproval with vehement jeers. A new workers' council was chosen the same day. ${ }^{22}$ The managing director and people in his close circle were not elected, but Balogh remained as chairman. On 11 November (after the launch of the Soviet counteroffensive), another workers' council was elected, and again Balogh remained the chairman. The council had 53 members. Indeed, the organizational culture of the party seems to have had an influence on the workers, because they also elected 29 alternate members. ${ }^{23}$ This relatively large body elected an 11-member presidium, which from the last days of October onwards (when the person who had previously held the position of managing director stopped going to the factory), dealt with the affairs of the company. According to data later compiled by the political police, skilled labourers formed the vast majority of the 83 -member council. There were very few so-called "déclassé elements" among them. In the usage of the Hungarian regime in the 1950s, this term referred to former army officers and members of the middle classes who had lost their former positions and had

21 A collection of memoirs and interviews with the one-time leaders of the workers' council, "Szuronyok hegyén nem lehet dolgozni". Válogatás, "1956-os munkástanács-vezetők visszaemlékezéseiből [One Cannot Work at the Tip of a Bayonet”. Selections from the Memoirs of the 1956 Workers' Council Leaders] (Budapest: Századvég K., 1993), 148-167. See in particular the interview with Sándor Rácz, chairman of the Workers' Council of Greater Budapest, $148-167$.

22 Similar processes took place at other enterprises. Workers' councils were created from above at first, and the leaders of the enterprise also served on them. A few days later, a new workers' council would be elected, on which the representatives of the plant management did not serve. Attila Szakolczai, “A győri vagongyár munkástanács: Bevezető tanulmány [The Workers' Council of the Győr Railway Coach Factory. Introductory Essay]”, in A győri vagongyár munkástanácsa. Dokumentumok [The Workers' Council of the Győr Railway Coach Factory], ed. Attila Szakolczai (Győr: Attila Szakolczai, 2007), 9-46.

23 The various bodies of the party were always comprised of members and alternate members. 
become workers of some sort, but who were still regarded as potential enemies of the socialist state. Most of the people on the council were from workingclass families or families with peasant backgrounds, and as far as their education was concerned, this comprised only the vocational training they had been given after having completed elementary school. ${ }^{24}$ The chairman, Ignác Balogh, was born in 1925 in Szamosszeg, a small village in eastern Hungary. He was a child of a peasant with just over four hectares of land. In 1944, Balogh had been given a position at the company that would later become Ikarus. In 1948, after the two workers' parties had been united, he had not been admitted into the new Hungarian Workers' Party, which meant he was also dismissed from his position. ${ }^{25}$ After having worked in various other places, in 1954 he was given a job at Ikarus again. Grandics, who as mentioned earlier served as deputy chairman of the council, was the chairman of the factory committee in the company which later became Ikarus, and he too had been a member of the Social Democratic Party. Like Balogh, he had not been welcomed as a member of the new Hungarian Workers' Party, though oddly enough, he was eventually allowed to join in September 1956 (one month before the outbreak of the revolution), when the decision originally made in 1948 was re-examined and he was rehabilitated.

The workers' council dealt at least in part with the economic affairs of the factory, for instance delivering the buses that had been ordered and finding solutions to enable the factory to pay wages. However, it also dealt with questions that belonged to the pressing topics of national politics at the time, as well as personnel issues within the company. The Ikarus workers' council unquestionably took a clear stance on questions that were unrelated to the factory itself, and it very clearly adopted positions in support of the revolution and in opposition to the Soviet intervention. The workers' council for district XVI, consisting of delegates sent from the factories in the area, was also formed in the Ikarus plant, since it was the largest enterprise in the district. Balogh became the chairman of this council as well, which also enabled him to become a

24 Historical Archives of the Hungarian State Security 3.1.9. V-150384/5. Budapest. Summary report of the VI/2. group of the Political Investigative Division of the Police Headquarters on the Workers' Council of the Ikarus Bodywork and Motor Vehicle Factory. 29 September 1959. Even when this report was issued, almost three years after the suppression of the revolution, the political police still felt that the "object remains a fairly infectious area from the perspective of the enemy".

25 The same thing happened to János Vörös, who had served as the secretary of the party organization of the Social Democratic Party at the company, and also to some of his colleagues when the two parties were unified. See Bódy, "Egy szocialista járműipari vállalat" [A Socialist Motorized Vehicle Enterprise]. 
member of the Greater Budapest Workers' Council. The Ikarus workers' council received leaflets from the Greater Budapest Workers' Council, of which it made copies that were then distributed among workers in the factory. Balogh often took part in sittings of the Greater Budapest Council. He brought leaflets from the council meetings to the factory and read out the resolutions over the public address system. ${ }^{26}$ The Central Workers' Council emerged as the body that, for a few weeks at least, functioned as a form of parallel power in opposition to the Kádár government, even after the Soviet soldiers had defeated the uprising and put an end to armed resistance. The Ikarus workers' council called for a boycott of the official newspapers of the Kádár regime, and in response to an appeal by the Greater Budapest Workers' Council in December, it actually organized a strike. Initially, it also attempted to hamper any organizational efforts on the part of the Hungarian Socialist Workers' Party within the company, when it tried to refuse to give the party organization any space in which to operate within the plant. The workers' council drafted, printed and distributed leaflets on 30 October and 13 November. These leaflets expressed the Ikarus factory employees' views and demands, which included the withdrawal of Soviet troops. In the case of the second batch of leaflets, printed after the Soviet attack, the demands also included the reinstatement of the Imre Nagy government, more specifically the last embodiment of this government, comprising a coalition of parties that had been revived. ${ }^{27}$

However, in addition to the stance adopted by the Ikarus workers' council to general political questions, it is also worth taking into consideration its activities within the factory, since the support of the broader segments of the workers definitely depended in no small part on them. The council had to have this support in order to maintain its presence in the factory from the end of October 1956 until March 1957, especially taking into consideration the fact that the regime forcefully rid itself of the Central Workers' Council on 11 December 1956 .

As far as changes within the factory were concerned, the council seems to have been led by a desire to see "justice" done in response to earlier events and processes. As part of this, on $3_{1}$ October, the presidium of the workers'

26 Historical Archives of the Hungarian State Security 3.19. V-141867. The investigation dossier on Dr Emil Hant and Associates.

27 Several parties were formed during the revolution, among them parties that had enjoyed widespread support in the period between 1945 and 1948, when they had formed the governing coalition. During the revolution, Imre Nagy, who was a member of the communist party, accepted a position at the head of a coalition government consisting of delegates of the parties that actually enjoyed the support of the people. 
council banned 38 employees from the plant, including the former director. As the list was being compiled, the head of the personnel division was summoned to appear before the council. He had been asked to name people in individual departments who had been stool pigeons. Undoubtedly alarmed by the course of events, the man did name a few people who were then added to the list of those to be banned. Essentially, all the members of the workers' council made suggestions concerning individuals from their spheres of work who should be banned. The council accepted the suggestions, though most of them did not actually know the individuals in question; only the person making the proposal. In an attempt to justify himself, Hant later alleged to the investigators that the people whose names had ended up on the list would have been at risk had they gone to the plant during the revolution, and thus the decision to ban them had actually been in their best interests. Patek simply contended that these "people had been banned from the factory because, as a consequence of their conduct in the earlier period, they had lost the trust of the workers". ${ }^{28}$ The list was signed by Balogh and his deputy, Béla Grandics, and was displayed on the notice board and the factory gates. According to some of the confessions made after the revolution, the factory guards were given instructions not to let the people on the list into the plant, but whether this actually happened is a question that remained unresolved in the proceedings of the political police. While the list was being compiled, the workers' council had also taken steps to seize the material in the personnel division, a measure that was implemented by council member Patek. Anyone who came to claim his or her professional documents and records was given them. The rest of the material was destroyed in the presence of witnesses. The delivery of personnel records to those concerned or the destruction of this material (which was a type of shared ritual of the revolution) was a symbolic act of the liberation of the individual from control from above and the triumph over fear.

These events, which historians can reconstruct on the basis of confessions later made to the police, show that the workers' council took measures against people who were regarded by its members as "communists". However, this term was not understood as a matter of ideological conviction. During the revolution, they regarded the leaders of the factory who had been appointed by the higher management as "communist" enemies, who had forced measures intended to increase production. This included wanting to transform work practices based on the expertise of the skilled labourers towards production

28 Confession of Alajos Patek, 18 April 1957. Historical Archives of the Hungarian State Security 3.19. V-141867. Investigation dossier on Dr Hant Emil and Associates. 
technologies that were more standardized and relied much less on individual contributions. The desire of the workers to maintain as much control as they could over the work practices was in harmony with the efforts of the engineers, whose goal was not to increase production from the perspective of quantity, but to produce new models which met high standards of quality. During the revolution, these two groups that shared common interests were able to take active steps and free themselves from the "communist" management. The workers were not enamoured of this management, which sought to maintain control over them and over production that was hardly innovative in terms of the technologies and expertise involved.

The workers were linked by the training they had received as skilled labourers, the similar positions they had held at the company and - at least some of them - by their membership of the Social Democratic Party before it had been essentially dissolved by the Communist Party. Between 1945 and 1948, Zerkovitz had also been a member of the Social Democratic Party, but he had become a member of the Hungarian Workers' Party immediately upon its founding, without any interruption in his status as a party member. Thus, the people who were active in the factory during the revolution seem for the most part at one time to have been members of the Social Democratic Party, and this clearly constituted a shared experience and common link. Cséfalvay, who had originally been a member of the Hungarian Communist Party, was an exception, having worked in the factory from the beginning of the Second World War. Alajos Patek was the only one of those arrested in the trial against the "counterrevolutionaries" at Ikarus who had never been a member of the Social Democratic Party or any political party. However - in common with the others who had accusations levelled against them - he had worked at the factory since 1940, although in the autumn of 1944 (during the Nazi occupation of Hungary), the Arrow Cross authorities had briefly arrested him because he had hampered the delivery of machines from the factory to Germany, that had been ordered by the Nazi authorities. Thus, during the revolution, the management of the factory ended up in the hands of people who, for the most part, had been working at the plant during the war (Balogh, Grandics, Patek and Cséfalvay) or who had been given positions in the immediate aftermath of it (Zerkovitz), and who at some point had been members of the Social Democratic Party (with the exception of Cséfalvay and Patek). ${ }^{29}$

29 As Standeisky has observed, in some revolutionary committees, people who had been active in the so-called coalition period immediately after the war also came into the foreground. Éva Standeisky, Népuralom ötvenhatban [Rule by the People in 1956] (Bratislava and Budapest: Kalligram, 2010), 306. 
During January 1957, by which time the Kádár regime has consolidated its hold on power, the Ikarus workers' council clearly refrained from taking any official political stance, although according to the political police, even then the "composition of the wc [Workers' Council] was bad". Again according to the information gathered by the police, in February the council was still trying to dismiss "communists" under the pretext of downsizing. ${ }^{30}$ On 7 March 1957, sensing that it was being rendered powerless, the council resigned; or to be more precise, the presidium resigned. This did not save the most important leaders of the council or the people in their immediate circle from being arrested; even while a new council was being elected, comprising people acceptable to the regime. On 13 and 14 March, Ignác Balogh, Emil Hant and Erzsébet Alberti were taken into custody, as was Alajos Patek on 1 April. Trials were launched against these four individuals for the "counterrevolutionary" events that had allegedly taken place at Ikarus. However, many other people were interned, including István Balázs, who had served as the commander of the factory guards during the days of the revolution. They were among the 26 people mentioned in the aforementioned monograph who were arrested, but in the course of the repressive measures taken by the regime in the months following the revolution, it was Balogh, Hant, Alberti and Patek who were condemned for "counterrevolutionary" activities at the Ikarus plant.

The investigation relied on interrogations of the detainees and witnesses, material evidence that had been gathered and searches of premises, including the private residences of the accused. The political police considered the confessions made by the accused and the witnesses statements (which were supposedly compared in an effort to ensure their reliability), together with the material evidence (which included leaflets and stencil machines), adequate proof that the accused were indeed guilty of having committed "counterrevolutionary acts".

On 18 October 1957, the court of first instance pronounced its verdict. Balogh was sentenced to three years in prison and a fine of 400 forint, Patek was sentenced to two years in prison and a fine of 600 forint, Hant was sentenced to two years and six months in prison and a fine of 1,00o forint, and Alberti - a typist who had kept the minutes during the sittings of the workers' council and had taken part in the duplication of the leaflets - was sentenced to seven months in prison. ${ }^{31}$ In the case of Balogh, the court recognized as a mitigating

30 Historical Archives of the Hungarian State Security 3.1.5. O-11804/1. Reports of the IV division of the II department of the National Police Headquarters from 4 January and 22 February 1957.

31 According to the verdict, Balogh, Patek and Hant were guilty of having taken active part in a movement that sought to topple the people's democratic state system. Patek was also 
circumstance that apart from his training as a skilled labourer, he had no education other than elementary school. Further, he had not been a figure who had incited or initiated insurrection, unlike the intellectuals who had led the company during the "counter revolution". This again raises the question of why Zerkovitz, who was one of these intellectuals, was not among the accused. On 3 March 1958, after appeals had been submitted by the prosecution and the defence, the Supreme Court announced its verdict. Balogh's sentence was unchanged and Patek's prison sentence was increased to four years and his fine to 1,00o forint. Hant's prison sentence was increased to 10 years and all of his property was confiscated. From the perspective of the regime, which was eager to consolidate its hold on power, this made perfect sense. As the court explained in its verdict, it regarded Hant as the leader in spirit of the counterrevolutionary events at Ikarus. Alberti's sentence was changed to one year in prison, and she was put on probation for three years (she had essentially already spent a year in custody by then). ${ }^{32}$

Other people could just have easily been chosen as scapegoats. As became clear on the basis of other confessions, from late October, Zerkovitz did indeed oversee the actual work of the factory, but he also took part in political acts. These included the drafting of leaflets, compiling the list of people who were banned from the plant and organizing the strike. As the chief engineer, Zerkovitz submitted suggestions to the workers' council concerning the replacement of two division leaders and the head of the personnel division; proposals that the council accepted. Zerkovitz also painted one of the leaflets issued by the central workers' committee onto a billboard and put it on the notice board.

guilty of aiding and abetting theft (because of the stolen stencil machine), and Hant was guilty of having served as an accessory to theft. Alberti was found guilty of having committed incitement against the people's democracy (i.e. the letters she had written to her two friends).

32 This summary of the events that took place at Ikarus during the revolution is based on the material from the investigation carried out by the political police, and documents from the subsequent trial. In all likelihood, it is not entirely reliable or complete. However, as far as the most important events are concerned, it is probably accurate, at least broadly, even if the confessions do not agree on every point. These differences may simply be due to the natural and inevitable differences in the ways in which people recall the same events, or they may be consequences of attempts on the part of the accused (and in part the witnesses) to defend themselves. It is likely, however, that some of the events or some of the acts committed by various figures did not come to the knowledge of the political police or were deliberately ignored. As noted, the sources offer no explanation for why Zerkovitz was not among the accused, nor do they explain why the authorities showed no interest in Cséfalvay, who had been a member of the Hungarian Communist Party since 1945. We only know that he left Ikarus as a consequence of the revolution. 
Zerkovitz, as part of the management of the plant, was present at every sitting of the council. The police officer in charge of the investigation even suggested to his superior that he "try to broaden the case with the inclusion of Zerkovitz". ${ }^{33}$ On 18 April 1957, a "summary report on the case of Béla Zerkovitz" was issued, according to which, "on the basis of the above, in our view, Béla Zerkovitz can be remanded into custody". ${ }^{44}$ However, he spent only one day in custody and was then released. Considering that there were suspicions concerning Zerkovitz a good four years before the outbreak of the revolution, it is all the more surprising that no case was brought against him in $1957 .^{35} \mathrm{He}$ was also not among the accused in the trial of those allegedly responsible for "counterrevolutionary" acts at Ikarus, in spite of the fact that several witnesses contended he had taken part in the drafting of both leaflets, had initiated changes in personnel and had been the leader in spirit of the workers' council. A worker in the factory who went by the code name "Rezső Németh" also contended this. Neither the documents used in the course of the investigation nor later material concerning Zerkovitz held in the historical archives of the Hungarian state security reveal why he was not in the end included among the accused. ${ }^{36}$ He was compelled to leave Ikarus, but for him, that was the only consequence of the revolution. ${ }^{37}$

33 Historical Archives of the Hungarian State Security 3.19. V-141867. The investigation dossier on Dr. Emil Hant and Associates. A suggestion was made in connection with the " $\mathrm{H}$ " report submitted by resident "Rezső Németh" as part of the further additional measures.

34 Historical Archives of the Hungarian State Security 3.19. V-141867. The investigation dossier on Dr. Emil Hant and Associates.

35 The earlier material concerning Zerkovitz (reports submitted by agents and expert assessments of the mistakes he allegedly made) were lost during the revolution. When the investigation was launched against him in 1957, the facts that allegedly spoke against him were based on the knowledge of the officials working on his case. Historical Archives of the Hungarian State Security 3.19. V-141867. The investigation dossier on Dr. Emil Hant and Associates.

36 There were other individuals against whom accusations could easily have been brought, but who were also left out of the trial. Their cases are as difficult to explain as that of Zerkovitz, if not necessarily as striking. The accusations brought against Hant included the charge that, after the Soviet forces attacked on 4 November, he had hidden a stencil machine with the intention of later using it to duplicate leaflets. No charges were brought, however, against the person who took the machine from an office of the Union of Working Youth during the revolution and hid it, at Hant's suggestion.

37 In a letter dated ${ }_{5}$ April 1957 and addressed to the Minister of Metallurgy and Engineering, the chairman of the executive committee of the Ikarus organization of the Hungarian Socialist Workers' Party, the director of the factory and the chairman of the new workers' council (which was loyal to the regime) asked that Zerkovitz be removed from Ikarus. They contended that he was unable to perform the organizational tasks of a chief engineer, his technical expertise notwithstanding, and that politically he was a turncoat 
During the revolution, engineers with considerable experience and firm views concerning the production of vehicles - such as Cséfalvay and Zerkovitz were able to play roles and were even able to act independently of the Ikarus former management, which had been appointed by the Ministry of Metallurgy and Engineering. They found partners among the skilled labourers, whose trust they clearly enjoyed.

The defeat of the revolution caused this circle to disperse. Zerkovitz managed somehow to avoid being brought up on charges, but he was not allowed to remain at Ikarus. Cséfalvay was also forced to leave the factory in 1957. Of the people who had served on the workers' council or had played significant roles in its operations, only Grandics remained at Ikarus, though he was demoted from workshop director to a mere worker. Many others outside of this circle left Ikarus (and perhaps the country). Hirmann's abovementioned report offers the following description of the situation. The "number of people working as designers, production engineers, and foremen, which was already low, suffered a serious loss because of the counterrevolution, a loss which I don't need to describe in detail here". ${ }^{38}$ These changes meant that the very model of production at the factory - which was based on the expertise of skilled labourers with experience in the fundamental work processes of bus manufacture, and which also involved continuous strife over wages and overtime pay - underwent a significant transformation because of the 1956 revolution. As Hirmann laments, with the loss of experienced skilled labourers and the core of specialists, it became impossible to continue production within the framework of the work culture that had existed before the revolution. This resulted both in failures in the planning and testing of new models (as mentioned earlier) and continuous problems with the manufacture of the models that were already in production. Hirmann offered the following description of the relationship between the engineering staff, many of whom were new, and the old skilled labourers: "since they have already seen many solutions, they think, 'what is this young engineer or technician doing explaining things to me, when I was making much better stuff back when he was still a kid"'. The undated record books of a later factory assessment,

who, one could easily sense, "would prefer to work in the service of the other system". Historical Archives of the Hungarian State Security 3.1.5. O - 16656/15. Dossier on Béla István Zerkovitz. 
probably from the late 195os, noted the lack of competent skilled labourers, and it insisted on the importance of regular production as the primary goal. Production was constantly interrupted and constantly falling behind. As a consequence of this, some of the individual factory units did not have anything to do at times, while at other times, they had to complete a huge amount of work relatively quickly.

Thus, though it unquestionably improved from the perspective of quality, production at Ikarus did not actually show "amazing development" - even before 1956 - since the company suffered continuous financial losses and there were always serious tensions among the employees and management that hindered production. After 1956, with the removal of many of the engineers and skilled labourers who had overseen manufacture, production along the lines of the earlier model was no longer possible at all. The old guard of skilled labourers end technical experts had enjoyed some degree of independence. Some of them, for example Cséfalvay, had belonged to the Hungarian Communist Party. In the wake of the revolution, however, many of them disappeared from the workplace, and others simply had their will broken. These changes gave the new management more power in its dealings with the workers, and also cleared the way for a new generation of engineers. The "two sides" that had earlier stood in opposition to each other at Ikarus - with a little oversimplification, employees who had begun their careers at the company owned by the Uhri brothers during the war, and those who had been made part of the management in the 1950s - disappeared as clearly defined opposing groups. One of the paradoxes of the revolution is that the young engineers brought in to replace people who had been dismissed from their posts at the factory also lost their positions because of the events of the revolution. Most of them had been military engineers involved in a programme designed around $195^{\circ}$ in preparation for the outbreak of the next world war. However, after 1956, preparation for a new world war was no longer an item high on the agenda of the regime, which in Kádár's quest for consolidation reduced military expenditure in order to fund a rapid rise in living standards. Many of the engineers whose training had focused primarily on military needs became superfluous, or were considered unreliable because of their conduct during the revolution. The Faculty of Military Engineering at the Budapest Technical University was closed. According to Pál Michelberger, who was a central figure among the engineers sent to Ikarus after the revolution (and who later had a very successful career), the bodywork for the busses in the period after the revolution was designed by aeroplane engineers and the mechanical engineering for the vehicles was carried out by people who had been trained as tank engineers. According to Michelberger, 
there was a need for a change of approach at Ikarus. Many people had left the country as dissidents. The aforementioned airplane engineers replaced them. ... They brought new constructions and new attitudes. They merged the traditional automobile with the idea of the airplane. One or two good engineering technologists came who solved the technological problems of mass series production. They automated [production]. They had tricks that you would not have been able to use for small production series. It was not for nothing that the 200 series was in production ... for 20 years. ${ }^{39}$

However, the new management and engineering staff only became able to tackle the complexities of production when, thanks to new investment - first in the paint shop and then in the production of bodywork with the use of large-capacity stamping machines - it managed to introduce a new industrial work culture. This made it possible to produce significantly larger series, in part by relying significantly less on the experience and expertise of skilled workers (though of course new problems emerged). Thus, the events of the revolution made it possible, or even necessary, to introduce change in the production technology at Ikarus. With what amounted essentially to the destruction of the work culture that had previously prevailed, it was simply no longer possible to continue production according to the methods and technologies that had been in use. This, however, belongs to the history of the investment programme of the 196os, which was founded on a fundamentally technocratic vision. ${ }^{40}$

In 1956, a significant number of the employees at the Ikarus factory clearly took positions. These positions touched on the major political questions of the revolution, but they also constituted stances with regard to the representatives of power at the factory itself. The group or network of workers and staff who were moved to act were linked by shared experiences before the nationalization of the plant. The tools with which the regime sought to compel workers to perform more effectively and efficiently set them against the system. They

39 Szentgyörgyi, Mérnök - tudós - iskolateremtő, 139.

40 See Zsombor Bódy, "Enthralled by Size. Business History or History of the Technocracy in the Study of a Hungarian Socialist Factory", Hungarian Historical Review 4 (2015): 964-989. 
put up lasting resistance to the changes that were implemented from above, and they insisted - at least as far as they were able to - on supervising and maintaining control over the work processes themselves. The engineering staff at the plant who disagreed with the higher bodies of economic policy on technical questions, shared their stance. During the revolution, they were able to take power into their own hands. It took the new factory leadership, which had been appointed by the Kádár government after the suppression of the revolution by the Soviet forces, months to eliminate the workers' council at Ikarus as an alternative centre of power. The series of events also made it necessary, however, for the factory to recruit a new circle of engineers and adopt new production techniques and technologies. These did not rely nearly so heavily on skilled labour, and gave workers far less leeway in the supervision of the production processes. The annual factory reports (and the monograph on the history of the enterprise) note that in the late 1950s and early 196os, the level of turnover among the workers was very high; in three years, it amounted to 75 per cent of the workforce. This shows that the workers, who enjoyed less control over production practices than had earlier been the case, had a weaker attachment to the factory. In addition, they were less likely to address their concerns within the factory by adopting collective strategies, which given the new level of technological automation, would no longer have been possible. In the search for better prospects, they were more likely simply to look for better job offers. ${ }^{41}$ This process was part of the larger effort of the Kádár regime to atomise society itself. ${ }^{42}$

\section{Bibliography}

Arendt, Hannah, The Origins of totalitarianism (Cleveland and New York: World Pub. Co., 1964).

41 Reports on Ikarus factory, Hungarian National Archives, Xxix F 187 - r 178. doboz Ikarus Karosszéria- és Járműgyár, Jenei - Szekeres, ibid. The struggle of workers in Hungarian industry to maintain some control over or say in the supervision of the work process naturally did not come to an end in the 1960s or the 1970s. According to István Kemény, during these two decades, it remained the most important source of conflicts in the workplace. István Kemény, "La chaine dans une usine hongroise", Actes de la Recherche en Sciences Sociales 24 (1978): 62-77.

42 János M. Rainer, “'A hatvanas évek' Magyarországon: (politika)történeti közelítések [The '196os' in Hungary:(political)historical approaches]", in A "Hatvanasévek” Magyarországon. Tanulmányok [The "196os" in Hungary. Essays], ed. M. J. Rainer (Budapest: 1956-os Intéze, 2004), 11-30. 
Belényi, Gyula, $A z$ állam szoritásában: Az ipari munkásság társadalmi átalakulása Magyarországon, 1945-1965 (Szeged: Belvedere Meridionale, 2009).

Bódy, Zsombor, "Egy szocialista járműipari vállalat születése”, Korall 52 (2013): 91-112.

Bódy, Zsombor, "Enthralled by Size. Business History or History of the Technocracy in the Study of a Hungarian Socialist Factory", Hungarian Historical Review 4 (2015): 964-989. Czére, Béla, and László Prohászka, Hazai Gépjármüközlekedésünk fejlesztése: A Magyar Tudományos Akadémia Közlekedéstudományi Föbizottsága és a Közlekedési Minisztérium által 1952. július 11-12-én rendezett első Gépjármüközlekedési Ankét előadásai és hozzászólásai (Budapest: Közlekedési Kiadó, 1953).

Géczi, József, and Éva Alajos-Szrenka, 8 napért 8 év. A munkástanácsok 1956-ban és ami utána jött ... (Szeged: Bába, 2012).

Haraszti, Miklós, Darabbér: Egy munkás a munkásállamban (Budapest: TEKA Könyvk., n.d.).

Jenei, Károly, and József Szekeres, Az Ikarus Karosszéria - és Jármügyár története 18951980 (Budapest: Ikarus Gyár, 1981).

Kemény, István, "La chaine dans une usine hongroise", Actes de la Recherche en Sciences Sociales 24 (1978): 62-77.

Kemény, István, Velüknevelkedett a gép. Magyar munkások a hetvenes évek elején (Budapest: Művelődéskutató Intézet, 199o).

Kemény, István, and Bill Lomax, Magyar munkástanácsok 1956-ban (Dokumentumok) (Paris: Magyar Füzetek, 1986).

Michelberger, Pál, “Előszó”, in Földön - vizen - levegőben. Uhri testvérek története 19411942, ed. Finta László (Budapest: Finta László, n.d.).

Rainer, János M., A “'hatvanas évek’ Magyarországon: (politika)történeti közelítések”, in A "Hatvanas évek" Magyarországon. Tanulmányok, ed. M. J. Rainer (Budapest: 1956os Intéze, 2004), 11-30.

Rainer, János M., "The Hungarian Revolution of 1956: Causes, Aims and Course of Events", in The 1956 Hungarian revolution: Hungarian and Canadian Perspectives, ed. Christopher Adam, Tibor Egervari, Leslie Laczko and Judy Young (Ottawa: University of Ottawa Press, 2010), 12-31.

Ripp, Zoltán, Forradalom és szabadságharc Magyarországon 1956-ban (Budapest: L'Harmattan, 2002).

Standeisky, Éva, Népuralom ötvenhatban (Bratislava-Budapest: Kalligram, 2010).

Szakolczai, Attila, "A győri vagongyár munkástanács: Bevezető tanulmány", in A győri vagongyár munkástanácsa. Dokumentumok, ed. Attila Szakolczai (Győr: Szakolczai Attila, 2007), 9-46.

Szentgyörgyi, Zsuzsa, Mérnök - tudós - iskolateremtö. Michelberger Pál és kora (Budapest: Typotex, 2008).

"Szuronyok hegyén nem lehet dolgozni". Válogatás, 1956-os munkástanács-vezetők visszaemlékezéseiből (Budapest: Századvég K., 1993), 148-167. 
Varjasi, Imre, Az 1956-os munkástanácsok tevékenysége és dokumentumai Hajdú-Bihar megyében (Hajduböszörmény: Fábián, 2008).

Zerkovitz Béla, “Újabb irányok az autóbusz építésben”, Magyar Technika: Müszaki és gazdaságtudományi folyóirat, no. 4 (1949): 45-51. 